\title{
THE CORE VALUES OF MODERN NURSING IN THE LIGHT OF DILTHEY AND SCHELER
}

\author{
Gilberto de Lima Guimarães ${ }^{1}$, Tania Couto Machado Chianca², Isabel Yovana Quispe Mendoza3, Vania Regina \\ Goveia ${ }^{4}$, Selme Silqueira de Matos ${ }^{5}$, Ligia de Oliveira Viana ${ }^{6}$
}
${ }^{1}$ Ph.D. in Nursing. Associate Professor in the Department of Basic Nursing at the Escola de Enfermagem (EE) of the Universidade Federal de Minas Gerais (UFMG). Belo Horizonte, Minas Gerais, Brazil. E-mail: drgilberto.guimaraes@hotmail.com
${ }^{2}$ Ph.D. in Nursing. Full Professor in the Department of Basic Nursing at EE/UFMG. Belo Horizonte, Minas Gerais, Brazil. E-mail: taniachianca@gmail.com
${ }^{3}$ Ph.D. in Nursing. Associate Professor in the Department of Basic Nursing at EE/UFMG. Belo Horizonte, Minas Gerais, Brazil. E-mail: isabelyovana@ufmg.br
${ }^{4}$ Ph.D. in Nursing. Associate Professor in the Department of Basic Nursing at EE/UFMG. Belo Horizonte, Minas Gerais, Brazil. E-mail: vaniagoveia@ufmg.br
${ }^{5}$ Ph.D. in Nursing. Associate Professor in the Department of Basic Nursing at EE/UFMG. Belo Horizonte, Minas Gerais, Brazil. E-mail: selmesilqueira@gmail.com
${ }^{6}$ Ph.D. in Nursing. Full Professor at the Escola de Enfermagem Anna Nery, Universidade Federal do Rio de Janeiro. Rio de Janeiro, Rio de Janeiro, Brazil. E-mail: ligiaviana@uol.com.br

\begin{abstract}
This study aimed to identify the values of modern nursing in the writings of Florence Nightingale entitled Notes on Nursing: What it Is, and What it Is Not, and justify them through some of the assumptions of Max Scheler's axiology. For this, we used Wilhelm Dilthey's hermeneutics as an instrument to unveil the Nightingale axiological field. From the effort undertaken in the search for the interpretation of the text, four core values of modern nursing were revealed from the researchers' consciousness, namely: solidarity; the value of truth; morality; and utility. These values form an amalgam and give nursing care sense and meaning. We concluded that these values make nursing what it is, legitimizing it as a social practice, and justifying the professional act. Thus, it is necessary for whoever undertakes this career to move themselves to the apprehension of values that form the axiological field, correcting or confirming the value of a scale itself, in order to form what it is to be a nurse.
\end{abstract}

DESCRIPTORS: Culture. Philosophy. Ethics. Education, nursing.

\section{OS VALORES FUNDADORES DA ENFERMAGEM MODERNA À LUZ DE DILTHEY E SCHELER}

RESUMO: Objetivou-se identificar os valores da Enfermagem Moderna no escrito de Florence Nightingale, intitulado "Notas sobre a Enfermagem - o que é e o que não é", e justificá-los através de alguns pressupostos da axiologia de Max Scheler. Para tanto, valeu-se da hermenêutica de Wilhelm Dilthey como instrumental para desvelar o campo axiológico nightingaleano. A partir do movimento empreendido na busca da interpretação do texto, foi desvelado, à consciência dos pesquisadores, quatro valores fundantes da Enfermagem Moderna, a saber: solidariedade, valor da verdade, moralidade e utilidade. Esses formam uma amálgama e dão ao cuidado de enfermagem sentido e significado. Concluiu-se que esses valores fazem da enfermagem o que ela é, legitimando-a como prática social, justificando o agir profissional. Faz-se necessário àquele que se insere na carreira mover-se à apreensão dos valores que formam o campo axiológico, retificando ou ratificando a própria escala valorativa a fim de constituir o Ser-enfermeiro.

DESCRITORES: Cultura. Filosofia. Ética em enfermagem. Educação em enfermagem.

\section{LOS VALORES FUNDAMENTALES DE LA ENFERMERÍA MODERNA A LA LUZ DE DILTHEY Y SCHELER}

RESUMEN: Este estudio tuvo como objetivo identificar los valores de la Enfermería Moderna en el documento de Florence Nightingale, titulado "Notas sobre Enfermería - lo que es y lo que no es", y justificarlos a través de algunos de los supuestos de la axiología de Max Scheler. Se utilizó la hermenéutica de Wilhelm Dilthey como instrumental para dar a conocer el campo axiológico de Nightingale. A partir del movimiento emprendido en la búsqueda de la interpretación del texto fue revelado a la conciencia de los investigadores cuatro valores fundamentales de la Enfermería Moderna, a saber: solidaridad, valor de la verdad, moralidad y utilidad. Estos valores forman una amalgama y dan al cuidado de enfermería sentido y significado. Se concluyó que estos valores hacen de la enfermería lo que es, legitimándola como práctica social, justificando el acto profesional. Es necesario que el que entra en la carrera se mueva a la aprehensión de los valores que forman el campo axiológico, rectificando o ratificando la propia escala de evaluación para constituir el Ser-enfermero. DESCRIPTORES: Cultura. Filosofia. Ética en enfermería. Educación en enfermería. 


\section{INTRODUCTION}

In the field of social practice is where we find the values proclaimed by past generations, and they can be accepted and lived by their participants coming from free choice and a personal hierarchy. ${ }^{1}$

Every human being belongs to an era and, as a social being, is part of the network of relationships that comprise it. They are immersed in a given culture, which nourishes them spiritually, and their appreciation of things conforms to rules and criteria, values that they do not invent, but that they discover and that give them a personal meaning. ${ }^{2}$

Nursing is embedded in social practice and it is there that it feeds on a set of values that give it meaning and significance. These values form an axiogram (hierarchical scale) of the profession, which is the evaluative self-declaration by which nursing is ruled, to guide and justify its actions. ${ }^{3}$

The search for understanding of the axiological field which demarcates the nursing profession is historical; in other words, it is founded on the very uniqueness of Florence Nightingale, an extremely important figure in the history of modern nursing. Knowing about her life and commitment helps us to interpret the role she played in building present-day nursing, guiding us through the paths of today. ${ }^{1}$

Furthermore, it was immersed in the social historical context of her time that she seized the values that she judged as being instituting for the science and art of nursing and which transcend her own time, allowing her to be recognized as someone through her way of acting.

Thus, the nursing profession was historically developed by Florence Nightingale, along with the educational system that evolved from it. Considering that this model was implemented in Brazil as far back as 1923, through the creation of the Anna Nery Nursing School, which today belongs to the Federal University of Rio de Janeiro, it is necessary to know about the profession inherited from identification with the values that she listed as foundational in modern nursing, in order to demarcate the criticism of current Brazilian nursing practice.

Due to the wear and tear acquired by the value of the word over time, it is important, in order to settle any doubt, to conceptualize it. In this study, we assume the value as that which is true for a human being to be able to meet a need and promote growth and development as a person. ${ }^{4}$
In order to support this reflection, we used some assumptions arising from Max Scheler's Theory of Value in the search for evaluative understanding, because it shares the view that values are perceived by feeling, and not by reason. ${ }^{5}$

The rationale for carrying out this work was focused on the reflective movement undertaken by the researchers during the exercise of their actions in education and care. There, in living with nurses, attending patients, in the pedagogical relationship with the students, and teaching the art and science of nursing, the values that were part of the axiological field that founded the inherited profession were asked about.

Given these considerations, this article aims to identify the values of modern nursing in Florence Nightingale's writing, entitled Notes on Nursing: What it Is and What it Is Not, and justify them through some of the assumptions of Max Scheler's axiology. ${ }^{5-6}$

\section{METHOD}

The reflective study, anchored on certain assumptions of Scheler's Theory of Value, has, in the hermeneutics proposed by Wilhelm Dilthey, its instrumental for understanding the reading of the text Nursing Notes: What it Is and What it Is Not. We attempted to clarify the meaning of modern nursing through an unveiling of Nightingale's axiological field. The choice of this writing was moved by the fact that it was the first construct available in the Portuguese language, becoming a milestone for the formation of nurses' awareness, and accessible to multiple generations of nurses in Brazil. ${ }^{1,7}$

Dilthey's hermeneutics, having been inspired by the philological hermeneutics of Schleiermacher, is considered the first strictly philosophical hermeneutics, as it raised hermeneutics from the status of mere interpretative technique to a comprehensive method.

Dilthey developed his thinking toward an understanding in terms of experiences, but only as it is limited to that obtained from written works, and he also distinguished between two types of understanding from experiential terms. The first was psychological understanding, which would work within the scheme of analogy with the experiences of others, to the extent that this socalled understanding is the incomprehension of a psychological being. The second was a higher or hermeneutic understanding which, in a more elaborate way, has meaning and significance as 
a target and distances itself from psychological understanding, as it is carried out through written works, understanding them as the spiritual products of independent living subjects. ${ }^{7}$

This second understanding played a central role in the unveiling of Nightingale's axiological field, because the experiences cannot be understood at all except as part of a whole - namely, life. And precisely because life and experience cannot be grasped from an objective plane of reality, a complete effort is necessary for the interpretation that passes through the subjective aspects of experience in order to reach their understanding. ${ }^{7}$

This objectification of uniqueness is obtained from the projection of internal states in the external environment, that is, in social practice. In no way does this uniqueness exist separately, because the historical subject is intrinsically inserted in its time and establishes relations with others. ${ }^{7}$

As a technique that allowed unveiling the values of modern nursing, Dilthey's hermeneutics were developed at two distinct moments. In the first, we tried to reconstruct the historical and social fabric that founded modern nursing, attempting to understand the elements that, objectively, could have influenced the life experience of Florence Nightingale.

In the process of textual analysis, it is essential that the interpreter have a pre-understanding, that is, information on the historical and social fabric that the author of the scenario founded because, without such prior knowledge, one cannot start the game of circularity. The hermeneutical method is characterized by a coming and going between the whole and its parts, as it is thus that one should be able to reach an understanding of the text. ${ }^{7}$

In this sense, the interpreter needs to put themselves in the author's position, both from the objective and subjective side. However, the objective side is given by the knowledge of the language used by the author and, subjectively, it is used to gain knowledge of their inner and outer life. It follows that both aspects can only be acquired completely through one's own interpretation. ${ }^{7}$

Therefore, the written text and the story of the author function as a whole, from which their thinking must be understood as something particular and vice versa. The result is that the interpretation of the text cannot be done all at once. In other words, after each new reading a little more is understood, because the knowledge necessary for full understanding is being incorporated. In the second phase, after a thorough reading of the text, the objective was the identification of the nursing values listed by Florence Nightingale that were unveiled to the consciousness of the researchers. Finally, the justification of these values was established based on some assumptions from Scheler's axiology.

\section{DEVELOPMENT}

\section{The historical and social fabric that founded modern nursing}

The emergence of modern nursing took as its starting point the rise of the bourgeoisie, especially from the context in which it entered English society in the late nineteenth century. There, with the increase in economic activity arising from industrialization, the need for labor regulation, combined with poverty reduction, occurred in due course. In this way, the necessary conditions were created so that there was an emergence of demands for better ways of life by some segments of the population. ${ }^{8}$

Thus began the movement for the reformulation of legal instruments for population assistance and, within this, the highlight was the reformulation of the Poor Law, whose emphasis was the conceptual distinction between poverty and pauperism. Poverty was perceived as being beneficial, because its resolution lay in the inclusion of the person in some activity of work; pauperism needed to be fought, as it entailed being a nuisance to the social order, in view of the refusal by the person to enter into any activity of work. ${ }^{8}$

Thus, only the miserable received social protection from the state and, in turn, they lost their political rights. This attitude reconciled the protection demanded by society and consolidated the ideology of modern care to the working class. ${ }^{8}$

The emergence of Florence Nightingale was marked by this context. The daughter of English parents, belonging to the haute (high) bourgeoisie, she was born in Florence in Tuscany. With a strong personality, she was zealous and determined, and possessed a vast general culture, superior to that of the women of her time, while maintaining a keen social sensitivity. The task of reporting the conditions of the hostels was delegated to her by a government commission. In the report, Florence stressed the importance of a classification of the people helped there. In 1867, there was a review of the Poor Law, and the government committee upheld their suggestions. ${ }^{8}$ 
The first effort in the search for organization in nursing occurred in 1860, with the establishment of the Nightingale School adjacent to St. Thomas' Hospital in London. With Nightingale's organization and the adoption of certain principles, the Nightingale paradigm was constructed, based on three guidelines, namely: 1) the school would be run by nurses; 2) it would implement a theoretical and practical teaching mode; 3 ) candidates would be selected from a physical, moral, and intellectual point of view. ${ }^{8}$

Florence intentionally proposed that nursing education should be performed within the hospital, but stressed that she should not be subordinated to the doctors, and thus would have her own hierarchy. ${ }^{3}$

The model had some influences that were incorporated by Nightingale for the organization of the new school, especially from the military model, highlighting Christian discipline and principles. ${ }^{3}$

Nightingale sought a break from the practice of nursing as exercised in her time, which was strongly influenced by mythical knowledge. Opposed to this model, Nightingale sought to promote closer relations between nursing and science. Therefore, she incorporated the requirements of the new scientific rationality and of epidemiology as a tool for the foundation of nursing education. ${ }^{3}$

It is possible to view the actions developed by Nightingale and her intention to promote changes in nursing from three areas, namely: in the field of division of labor; in the field of healthcare; and in the field of teaching.

In the field of division of labor, in the model proposed by Nightingale the dichotomy that was born in nursing between intellectual and manual work is evidenced, identified in the lady-nurse and nurse figures. The former was in charge of the conduct of the process of organization, supervision, leadership, and instruction. She held a privileged socioeconomic and cultural position in English society, whereas the nurse had the task of implementing the manual labor and had a lower social status. ${ }^{9}$

It is estimated that, by establishing the division of labor from the distinction between social classes, Nightingale created a new and respectable occupation for the ladies of society, coming from the bourgeoisie. Thus, she inserted in nursing people who could give respectability to the career, because they belonged to the middle and upper strata of British society.
In the field of healthcare practice, Nightingale described the mode as watching the person focused on caring for human nature, stating that the nurse should develop rigorous skills of observation. Based on this method, she would establish the form of intervention. It appears that, after employing this method of observation, Nightingale started to evaluate the characteristics of the environment and its impact on the health-disease relationship..$^{10}$

She emphasized that the environment needed to be seen in a comprehensive way, in order to favor the recovery of the sick; it should have good conditions for care, with regard to aeration, lighting, cleanliness, and heating. The use by Nightingale of her empirical method enabled her to lay the foundation for the construction of what, simultaneously, came to be identified as the environmental theory in nursing. ${ }^{11}$

In the teaching field, Nightingale promoted the introduction of nursing candidates with a "good nature." This action led to an improvement in the level of care, strengthening the construction of the figure of the nurse as the guardian of morality. The measure came to meet the aspirations proclaimed in the Victorian era, in which women had the attribute of performing four virtues, namely: piety; purity; submissiveness; and domesticity. Thus, the identification of females as representative of the emerging model was constructed. ${ }^{8}$

During the course at the Nightingale School, students lived in a boarding school regime, subject to strict discipline, in order to develop the character traits considered desirable, such as sobriety, honesty, loyalty, punctuality, serenity, organizational spirit, elegance, and correction. These nurses, as they were being trained, were ready to perform the office of healthcare and the activity of teaching. ${ }^{9}$

\section{Identification with the values of modern nursing}

In the following section, we present the four values that arose from the awareness of researchers during the process of Dilthey's hermeneutic analysis, namely: solidarity; the value of truth; morality; and utility.

These were identified as belonging to the axiological field that founded the profession. They have been laid out in this article from their appearance throughout the text. The first was solidarity, found in Nightingale's affirmation when she said: 
"Matrons! Do those that speak thus, by chance, know that in this civilized England, one out of every seven children dies before reaching one year of age? That in London, two in five die before five years of life? [...] Or is it that all this suffering and premature death are needed?". 6:163

Her understanding of the value of human life and its relation to the social context played a motivating role in her thinking. Her attitude reveals the search undertaken for the transformation of the reality in which she operated from the lucid and conscious action of the nurse. It reveals that awareness of citizenship is part of the action of nursing.

The second value was the value of the truth. Its establishment in social practice is scientific knowledge. It was located in Nightingale's thinking when she said: "[...] the nurse must thus understand the whole changing physiognomy of their patient. You should study it, until you feel sure that no one else understands it as well as you $[\ldots]^{\prime \prime} \cdot 6: 163$

Thus, the knowledge gained through rigorous observation constitutes the genesis of the scientific spirit. Mythical knowledge would no longer be the guide for nursing actions, but rather that knowledge arising from systematic observation. Now, nursing was approaching the requirements of modern scientific rationality.

The third value was morality, found in the following assertions from Nightingale when she said: " [...] to the ladies who call themselves nurses and who have not learned the ABC of a nurse's education. The " $A$ " [...] should be the knowledge of what it means to be a human patient [...] and recognize them not as an animal [...] what it means to feel a vocation for something? It won't be performing their work in order to meet their own elevated concept of what is right, the best [...] if they do not give aid to their patients, no lecture will be able to do it". ${ }^{6: 163}$

The nurse has the responsibility of aiding the client, not only for recognition of their biological life, but for being a person. Their act is subject to evaluation from the direction for the practice of good, understood as a marker for their professional attitude.

The fourth value was utility. Nightingale expressed it by stating that: "[...] the nurse's duty includes checking the pulse, observing the diet, sleep $[\ldots]]^{\prime \prime} .: 166$ It was inferred that, by using the word "includes," Nightingale lets us imply that the nurse's action does not end only in providing this value, but it is used to perform the art of caring.
It is important to highlight that the values of the profession cooperate in the development and growth of all the subjects involved in the process of nursing care, reaching professionals and students. Because, to Max Scheler, these are the values that allow the human being to become a better person. ${ }^{5}$

The values listed by Nightingale and identified by researchers in the writing Nursing Notes: What it Is and What it Is Not, are instituted in modern nursing. They are constituted in an amalgamation and they assume a sense of duty-being by healthcare nurses, and on the part of teachers, researchers, and students, revealing the peculiar axiological route to nursing.

It is believed that the values proclaimed by Nightingale are not restricted to her time. They transcend space-time. It is up to those participating in a nursing career - that is, healthcare professionals, educators, and students - to express these values, each in their own time and judgment, because they constitute their own professional identity.

\section{The values of modern nursing from Scheler's perspective}

Having identified, in the writings of Florence Nightingale under review, four founding values, namely: solidarity; the value of the truth; morality; and utility, it is necessary to justify them from some constituent elements of Scheler's theory.

The phenomenology of Max Scheler, taking its inspiration from Husserl, is above all a philosophy of values. Its intention is to build ethics based on an objective and rigorous database, from which arises an axiology of absolute essentials opposing axiological rationalism. The values are revealed through emotional intuition. By doing so, one rejects the distinction between sensory and rational knowledge, raising the emotional to the rational level, allowing for a world of experiences whose objects are inaccessible to understanding. Only the emotional places human beings authentically in this world, a characteristic that sustains Scheler's axiology. ${ }^{5}$

\section{Solidarity}

It is what favors human life inserted in society. Analyzing society from the I-you relationship, Scheler builds the case that only the understanding of the human being as a person is that in which one can develop the ideal society. ${ }^{5}$

For him, the analysis of the social reality is based on the phenomenological concept of in- 
tentionality and the concept of the person as the center of intentional acts. It is from this element that he seeks to understand and grasp the essence of what constitutes the different basic types of human groupings, namely: mass; vital community; society; and the ideal society. ${ }^{5}$

Mass is characterized by the total absence of any meaning or intent; it is an unstable element in the relationship between individuals. Living inserted in it, one is bound to perceive the other as an object and remain in a state of alienation. In a vital community, typical of tribal groups, there is no distinction between mine and yours, because the living experience is identical for everyone. While in mass there is no form of solidarity, in vital community there is only that which denominates the solidarity of replacement, in which one individual is replaced by another. Therefore, it is not about true solidarity, because there is no recognition of the personal uniqueness of the other. ${ }^{5}$

In society, the association is conscious and voluntary. Understanding and mutual relationships between members occur through analog inference, which consists of assigning an individual reality to the other that is not lived, simply deduced. This results in a total separation between individuals, without a true, original, and essential shared responsibility. What exists is an individual self-responsibility without real communication between members, because their relationship does not reach the personal level. ${ }^{5}$

As opposed to the social groupings analyzed, Scheler proposes a new one, which he calls the ideal society. It is the desired point of growth and development of human beings in a social value. In it, the person is self-responsible and co-responsible for others and establishes solidarity as a must. ${ }^{5}$

Consequently, the social value from the solidarity of care and education is key to building the nurse being, because in nursing practice, whether in healthcare or education, the various actors will be taking their commitment to the world, life, and the person. They seek to recognize their place in the cosmos and their respective role in transforming the oppressive reality of health afflicting the Brazilian population. ${ }^{3,12}$

\section{Value of the truth}

The truth can be considered a value, not for its content, but because it corresponds to the human yearning to understand the real, because man is not satisfied with error and falsehood. He wants and longs to know the truth. His incompleteness is not resolved by deception. Only the truth has the opportunity to complement him. ${ }^{4}$

Scheler's proposition asserts that scientific knowledge is the established truth; therefore, science is a phenomenon resulting from man's rational construction. Reason is improved, when switching from common sense to the scientific, from the effort in the organization of knowledge. ${ }^{5}$

Historically, in nursing, the movement in the recognition of scientific knowledge as a guide to practice of care dates back to the 1950s, when it sought to take shape seeking a rationale for the techniques employed, approaching the basis of natural sciences and of medical knowledge. Furthermore, the science of nursing will draw on knowledge from the areas of health and human sciences, in order to constitute the body of knowledge that will support its action. ${ }^{3}$

\section{Morality}

It is the good that appears requiring an intention of love. It takes place in social practice, through good works. As a value, is projected in the world as a must. It is expressed in the form of a categorical imperative; that is, it imposes itself faced with bringing to the playing field its respective influence and thereby rectifying its action. Therefore, it becomes possible to transform reality from the spiritual growth resulting from the presence of good within each individual. ${ }^{5-4,13}$

Human beings feel the need for good and, of course, tend to view it as a value. In this respect, good presents itself as an end. Reason, based on reflection, will establish a moral conscience, which is expressed by value judgments that appear at ease, leading to seeking good as its objective.,14

For modern nursing, this value works for the construction of the nurse being, by providing the nurse with the possibility of giving meaning to their attitude by focusing on doing good. Therefore, watching life takes on a dimension that transcends the biological because respect, dignity, honesty, and moral integrity are replaced by a requirement in the attitude of the nurse being.,14

At the same time, in Scheler's perspective, it is for love that we enter the person's reality. Through other means, such as the rational and scientific, we can understand character and temperament; however, we can never distinguish one person from the other. Thus, through these methods, we only identify data, signals, and particu- 
larities, and we ignore that which the individual belongs to. In this sense, we must recognize the patient not just as a collection of logical data, but also as a subjectivity. Therefore, for nursing, the premises of Scheler's thinking can contribute in the pragmatic, strengthening it philosophically and subsidizing the exercise of ethics based on principles, in which love becomes foundational to the establishment of care..$^{13-14}$

\section{Utility}

It is what favors life - not life in general, but human life. Man's life is not independent of humanity. Man is spirit, and at the same time he is life. ${ }^{5}$ For animals, the value of utility corresponds to the vital value; not so for man. Even though in the early stages of development in a child's life the natural overlaps the artificial, in adults, and especially in the acculturated, the artificial prevails over the natural. ${ }^{4}$

Usefulness can be regarded as a spiritual value because it is oriented not only to the preservation of life, but to the spiritual development of the individual. It shows the statement of an organization of life by the spirit, and not the submission of the spirit to life. ${ }^{5}$

Scheler's criticism of modern capitalist society is that, from the bourgeois influence, it has undertaken efforts to develop, together with people, a hierarchy of values whose utility value has been placed on top. He carries out his condemnation of this inversion of values from the bourgeois ethos, an inversion that consists of placing, at the top of axiological hierarchy, accurately, the sensitive and material values, which should occupy the lowest level. It is enough to adequately reorder this hierarchy, assigning to spiritual values the primacy that is theirs by right, to eliminate any negative sense of technological progress and of modern industrial civilization. ${ }^{5}$

Thus, technique and industry should be put back in their proper place, as they are an important support and even essential for the development of the spirit and culture. In this sense, modern civilization produced by capitalism is, in its thinking, its own justification, with an absolutely positive meaning. What Scheler criticizes and condemns is the inversion of values from the bourgeois ethos, not specifically what it produced in terms of technological and industrial progress. ${ }^{5}$

For the pragmatics of nursing, this utility value takes on importance, given the variables that come from its base, namely: technique; organization; leadership; and the rationalization of time or materials that bring about strong implications for the work performed together with the client and the community. ${ }^{3}$

However, we make use of Scheler's assumption, which says that life hides in itself the very values that never let it reduce the useful values or perhaps the technical values. Thus, the strongest life will not be the one that puts activity with maximum suitability in place, because the strongest life is one that, with a minimal mechanism, grows and progresses. ${ }^{5}$

That said, it is stated that the value is not restricted to attend a facet that composes it. It is in the value of the utility that the dimensions of being-in-the-world have meaning for human beings. Thus, hearing, touching, talking, being at each other's side, and other bodily expressions are forms of appearance with a useful value. It is through this value that nursing care encourages the completeness of the human-person.

\section{CONCLUSION}

By way of conclusion, it can be said that modern nursing has an axiological field that is peculiar. The values that make up this field have been identified in the writing of Florence Nightingale, and they are: solidarity; the value of the truth; morality; and utility. These values make nursing, insomuch as we have inherited and know it, what it is; they legitimize it as a social practice and justify the professional way of acting.

When unveiling the axiological field of the profession, it allows us to reflect on the care that nursing dispenses to the patient, attempting to understand its successes and contradictions. In the process, it allows us to identify it as the fulcrum of professional action, recognizing it as an act of love and solidarity, based on scientific and technical expertise. Therefore, through the care rooted in the values of the profession, scientific objectivity and subjectivity are joined together. This link fosters a sense of duty in the nurse, as it allows them to recognize the patient as a person.

Thus, it becomes necessary to those who, in this career, form part of the movement to seize the values that make up its axiological field. It is not about a simple transfer, but rather a personal redefinition; that is, through reflective movement, applicants for the profession of nursing and those who are already nurses will bring about their very 
own axiological scale, allowing it to be criticized and comparing it with the values of modern nursing as propounded by Florence Nightingale, and thus rectify or ratify the actual evaluative scales in agreement with the axiological field that establishes the profession. This referral is essential, because its non-realization will produce, in the subject, a weakening in the building of nursing people.

\section{REFERENCES}

1. Carvalho V. Ética e valores na prática profissional em saúde: considerações filosóficas, pedagógicas e políticas. Rev Esc Enferm USP. 2011; 45(Esp 2):1797802.

2. Souza ML, Sartor VVB, Padilha MICS, Prado ML. O cuidado em enfermagem - uma aproximação teórica. Texto Contexto Enferm. 2005 Abr-Jun; 14(2):266-70.

3. Guimarães GL, Viana LO, Matos SS, Carvalho $\mathrm{DV}$, Baroni FCAL. O valor verdade no ensino da enfermagem: um estudo fenomenológico. Rev Gaúcha Enferm. 2013; 34(1):133-9.

4. Werneck VR. Novos valores ou nova hierarquia de valores? Meta: Avaliação. 2010; 2(4):73-86.

5. Scheler M. Le formalisme en éthique et l'ethique matériale des valeurs. Paris (FR): Gallimard; 1955.

6. Nightingale F. Notas sobre a enfermagem: o que é e o que não é. São Paulo (SP): Cortez; 1989.

7. Dilthey W. Introdução às ciências humanas: tentativa de uma fundamentação para o estudo da sociedade e da história. Rio de Janeiro (RJ): Forense Universitária; 2010.

8. Sauthier J. A missão de enfermeiras norte-americanas na capital da República 1921-1931 [tese]. Rio de Janeiro (RJ): Universidade Federal do Rio de Janeiro, Escola de Enfermagem Anna Nery; 1996.

9. Silva GB. Enfermagem profissional: análise crítica. $2^{\mathrm{a}}$ ed. São Paulo (SC): Cortez; 1989.

10. Caccavo PV. A arte da Enfermagem: efêmera, graciosa e perene [tese]. Rio de Janeiro (RJ): Universidade Federal do Rio de Janeiro, Escola de Enfermagem Anna Nery; 2000.

11. Tonolli EAS. O movimento de reconceptualização da Enfermagem Brasileira de 1970 a 1990 [tese]. Rio de Janeiro (RJ): Universidade Federal do Rio de Janeiro, Escola de Enfermagem Anna Nery; 2001.

12. Alves VH, Rodrigues DP, Gregório VRP, Branco MBLR, Souza RMP, Alves CMCSH. Reflexões sobre o valor da amamentação como prática de saúde: uma contribuição da enfermagem. Texto Contexto Enferm [online]. 2014 Jan-Mar [acesso 2015 Abr 23]; 23(1):203-10. Disponível em: http:// www.scielo.br/ pdf/tce/v23n1/pt_0104-0707-tce-23-01-00203.pdf

13. Medeiros MB, Pereira ER, Silva RMCRA, Silva MA. Dilemas éticos em UTI: contribuições da Teoria dos valores de Max Scheler. Rev Bras Enferm. 2012 MarAbr; 65(2):276-84.

14. Carneiro AD, Costa SFG, Pequeno MJP. Disseminação de valores éticos no ensino do cuidar em enfermagem: estudo fenomenológico. Texto Contexto Enferm. 2009 Out-Dez; 18(4):722-30. 